NBER WORKING PAPER SERIES

INTERNATIONAL MONETARY COORDINATION AND THE GREAT DEVIATION

\author{
John B. Taylor \\ Working Paper 18716 \\ http://www.nber.org/papers/w18716 \\ NATIONAL BUREAU OF ECONOMIC RESEARCH \\ 1050 Massachusetts Avenue \\ Cambridge, MA 02138 \\ January 2013
}

For helpful comments I thank participants of the Federal Reserve Bank of Dallas Globalization \& Monetary Policy Institute, where I serve as Chair of the Advisory Board, at the Bank for International Settlements June 2012 Conference on The Future of Financial Globalization, and the Hoover Institution's Working Group on Economic Policy, where I serve as chair. The views expressed herein are those of the author and do not necessarily reflect the views of the National Bureau of Economic Research.

NBER working papers are circulated for discussion and comment purposes. They have not been peerreviewed or been subject to the review by the NBER Board of Directors that accompanies official NBER publications.

(C) 2013 by John B. Taylor. All rights reserved. Short sections of text, not to exceed two paragraphs, may be quoted without explicit permission provided that full credit, including $\odot$ notice, is given to the source. 
International Monetary Coordination and the Great Deviation

John B. Taylor

NBER Working Paper No. 18716

January 2013

JEL No. E5,E58,F3

\begin{abstract}
$\underline{\text { ABSTRACT }}$
Research in the early 1980s found that the gains from international coordination of monetary policy were quantitatively small compared to simply getting domestic policy right. That prediction turned out to be a pretty good description of monetary policy in the 1980s, 1990s, and until recently. Because this balanced international picture has largely disappeared, the 1980s view about monetary policy coordination needs to be reexamined. The source of the problem is not that the models or the theory are wrong. Rather there was a deviation from the rule-like monetary policies that worked well in the 1980s and 1990s, and this deviation helped break down the international monetary balance. There were similar deviations at many central banks, an apparent spillover culminating in a global great deviation. The purpose of this paper is to examine the possible causes and consequences of these spillovers, and to show that uncoordinated responses of central banks to the deviations can create an amplification mechanism which might be overcome by some form of policy coordination.
\end{abstract}

John B. Taylor

Herbert Hoover Memorial Building

Stanford University

Stanford, CA 94305-6010

and NBER

John.Taylor@stanford.edu 


\title{
International Monetary Coordination and the Great Deviation
}

\author{
John B. Taylor ${ }^{1}$ \\ Stanford University \\ January 2013
}

\begin{abstract}
$\underline{\text { Abstract }}$
Research in the early 1980s found that the gains from international coordination of monetary policy were quantitatively small compared to simply getting domestic policy right. That prediction turned out to be a pretty good description of monetary policy in the 1980s, 1990s, and until recently. Because this balanced international picture has largely disappeared, the 1980s view about monetary policy coordination needs to be reexamined. The source of the problem is not that the models or the theory are wrong. Rather there was a deviation from the rule-like monetary policies that worked well in the 1980s and 1990s, and this deviation helped break down the international monetary balance. There were similar deviations at many central banks, an apparent spillover culminating in a global great deviation. The purpose of this paper is to examine the possible causes and consequences of these spillovers, and to show that uncoordinated responses of central banks to the deviations can create an amplification mechanism which might be overcome by some form of policy coordination.
\end{abstract}

Research in the early 1980s with empirical multi-country monetary models found that the gains from international coordination of monetary policy were quantitatively small compared to simply getting domestic policy right. ${ }^{2}$ To be precise, the models showed that if each central bank in a flexible exchange rate system followed a policy rule which optimized its own country's domestic macroeconomic performance - under the assumption that other countries would do the same - then there would be little additional gain from the central banks' jointly optimizing policies. In game theory terminology, macroeconomic performance under a Nash non-

\footnotetext{
${ }^{1}$ Presented at the Session on International Policy Coordination, American Economic Association Annual Meetings, San Diego, California

${ }^{2}$ See, for example, Oudiz and Sachs (1984) and Taylor (1985). These estimated or calibrated models generally incorporated rational expectations, price rigidities, and perfect capital mobility
} 
cooperative monetary policy is nearly as good as the under the optimal cooperative monetary policy, and far superior to a policy which is suboptimal on purely domestic grounds.

That prediction turned out, in my view, to be a pretty good description of monetary policy in the 1980s, 1990s, and until recently. As central banks moved toward more rules-based policies — with strong emphasis on domestic price stability and little emphasis on international coordination of the policy rules for the instruments - macroeconomic performance improved dramatically. It is hard to see how more international monetary policy coordination could have improved macroeconomic stability in the advanced countries much further during the Great Moderation. Indeed, there was a balance in the international monetary system in which central banks chose policies mainly with domestic considerations in mind and thereby contributed to better global economic conditions. There was little concern about adverse spillover effects and, especially toward the later part of this period, central banks in emerging market countries began moving from highly discretionary crisis-prone policies toward steadier policies with long-run price stability goals. Thereby they also began contributing to the overall global monetary balance.

But in recent years this balanced international picture has largely disappeared. The United States experienced a serious boom-bust financial crisis and a great recession with repercussions throughout the world, and it is now experiencing a painfully slow recovery. Policy makers in emerging market countries have been registering strong complaints about adverse spillover impacts of monetary policy on their economies. Policy makers in some developed countries such as Japan are expressing concerns about currency wars and competitive devaluations due to monetary policies in other countries. At the same time central bank independence, which was critical for the good performance in the 1980s and 1990s, seems to be 
eroding as the political authorities demand more from central banks, and central banks voluntarily engage in policies beyond the normal scope of monetary policy. Not surprisingly the head of the BIS has begun calling for international monetary policy coordination, and, also not surprisingly given current disagreements, his call is viewed as quite controversial by a number of central bankers. ${ }^{3}$

Clearly the 1980s view about monetary policy coordination needs to be reexamined in light of recent events. In my view the source of the problem is not that the models or the theory are wrong, but rather that the policy assumptions that went into the theory changed. In particular there was a deviation from the rule-like monetary policies that worked well in the 1980s and 1990s, and this deviation helped break down the international monetary balance. Empirical research shows that this deviation started happening in the United States about a decade agoaround 2003-2005—when interest rates were held low. ${ }^{4}$ But empirical research also shows that there were similar deviations at many other central banks, an apparent spillover culminating in a Global Great Deviation as pointed out and documented by Ahrend (2010) and Hofmann and Bogdanova (2012). The policy deviations in other countries are in close synchronization with that of the United States, and are similarly characterized by policy interest rates that were low relative to simple rules that described policy during the Great Moderation. Hofmann and Bogdanova (2012) show that the deviation began around 2003 and that it is continuing to the present - especially when the unconventional central bank interventions and large-scale balance sheet operations are included.

The purpose of this paper is to examine the possible causes and consequences of these spillovers of policy deviations, and to show with a simple model that the uncoordinated

\footnotetext{
${ }^{3}$ BIS General Manager Jaime Caruana's (2012a) speech and discussion at Jackson Hole and his more detailed follow-up speech in Uruguay (2012b).

${ }^{4}$ See, for example, Taylor (1977b) and Kahn (2010).
} 
responses of central banks to the deviations creates an amplification mechanism that might be overcome by some form of policy coordination. These issues have implications for the causes of the global financial crisis, the recent slow recovery, and international monetary policy going forward.

\section{Reasons Why Monetary Policy Deviations Go Global}

I focus on the unusually large deviations of policy interest rates from policy rules that described policy well in the 1980s and 1990s with particular emphasis on negative deviations where the interest rate is too low. There are a number of reasons why an unusually low interest rate at one central bank puts pressures on central banks in other countries to also choose unusually low interest rates.

First, in a wide variety of open economy monetary models with rational expectations and capital mobility, arbitrage forces tend to align the rate of return in different currencies. Thus, a very low federal funds rate or promises of a very low rate in the future, for example, will tend to cause a depreciation of the dollar and a corresponding expected appreciation of the dollar which compensates for the lower dollar interest rate. This depreciation effect on the dollar is, of course, an appreciation in other currencies and exists in most empirical monetary models. ${ }^{5}$ However, many central banks will tend to resist large appreciations of their currency, and one way to do so is to cut their own policy rate. This will reduce the gap between the federal funds rate and the other country's interest rate and will thus mitigate the appreciation of their exchange rate.

Second, as shown in a recent paper by Bruno and Shin (2012), low policy interest rates at major central banks can increase risk-taking in other countries, and one way to combat this is to

\footnotetext{
${ }^{5}$ See the open economy models in the model data base constructed and maintained by Volker Wieland (2009).
} 
lower interest rates abroad. In the Bruno-Shin model, firms abroad borrow in dollars to finance their projects even though the returns on these projects are denominated in local currency. The loans made to the firms by banks to fund these projects are subject to default risk in the event that the project earns less than the loan, including interest payments.

Banks that lend to these firms take account of this default risk by using a "value at risk" approach. Accordingly, banks increase the size of the loans on the project up to the point where the amount that must be paid back (including interest) results in a probability of insolvency of the bank that just equals a given value. Let the amount to be paid back be $(1+\mathrm{f}) \mathrm{L}$, where $\mathrm{f}$ is the interest rate and $\mathrm{L}$ is the loan. The higher is $(1+\mathrm{f}) \mathrm{L}$, the higher is the default risk, and, for a given value at risk, the lower is $\mathrm{f}$, the higher is L. In other words, a reduction in the interest rate increases lending and encourages more risk taking on the part of these firms. This initial effect is amplified because when the federal funds rate is reduced and L rises, the exchange rate appreciates. The appreciation reduces the likelihood of default because local currency then converts into more dollars to pay back the loan. This enables the banks to lend more, which in turn causes the exchange rate to appreciate further. In other words there is a dynamic process with lending responding to the exchange rate and the exchange rate responding to lending. The process converges, but the eventual impact is larger than the initial impact. ${ }^{6}$

One way that a central bank can offset the increase in foreign lending is simply to keep its own interest rate low. This reduces the incentive to borrow abroad and also reduces the magnification effect by keeping the exchange rate from appreciating. In effect, an extra low interest rate policy in one country leads to a similar deviation in other countries.

\footnotetext{
${ }^{6}$ While the magnitudes of these effects are uncertain and depend on the special value-at-risk assumption, Bruno and Shin provide estimates of the overall effect on risk taking by estimating time series models. They find interest rate effects on risk taking as measured by the VIX, which are similar to the results of Bekaert, Hoerova, and Duca (2010).
} 
A third reason for an association between policy deviations in different countries is the existence of a common global shock. Of course the financial crisis itself is an example of a shock, and it is natural to argue that the recent multitude of policy deviations was a common response to this shock. However, because the financial crisis occurred after the policy deviations began, it is an unlikely candidate for such a shock. Another example comes from the research by Hofmann and Bogdanova (2012). They empirically estimate simple policy rules in recent years for a number of countries and find that the deviations can best be interpreted as due to a change in the global equilibrium real rate of interest rather than to a change in the reaction coefficients.

There are other possible reasons for the correlation between policy deviations in different countries. Central bankers may simply follow each other. In the debate about rules versus discretion, the case for discretion might become more popular thereby removing the incentive to follow rules-based policies. Or governments in one country may become more aggressive in challenging central bank independence if other central banks appear to be losing their independence.

\section{Empirical Evidence of Spillovers through Central Bank Interest Rate Responses}

Regardless of the reasons, there is considerable empirical evidence of the impact of foreign interest rates on central bank decisions. Perhaps the best evidence comes from reports from central banks themselves. Consider the Norges Bank, for example, which is one of the most transparent central banks regarding the reasons for its policy decisions. ${ }^{7}$

Figure 1 shows two charts which illustrate the reasons behind a decision by the Norges Bank to lower its policy interest rate and the forecast of the policy rate. The change occurred in

\footnotetext{
${ }^{7}$ The following information is drawn from several Monetary Policy Reports of the Norges Bank and was used in a presentation that I made at the Norges Bank in Taylor (2010). For more information on monetary policy in Norway see Røisland (2010) and OECD Survey (2010).
} 
2010. The top chart shows the interest rate decrease — from the black dashed line to the red dashed line. The lower chart shows the reasons for the interest rate changes according to the Norges Bank report. The red bars in the lower chart show that the main reason for the lower interest rate choice in Norway was lower interest rates abroad.

Figure 2 shows two similar charts illustrating the reverse case of an increase in the interest rate in 2008. The top chart shows the increase in the Norges Bank's policy interest rates-from the black dashed line to the red dashed line. The blue bars in the lower chart show that the main reason for the increase in Norway was the increase in interest rates abroad. 


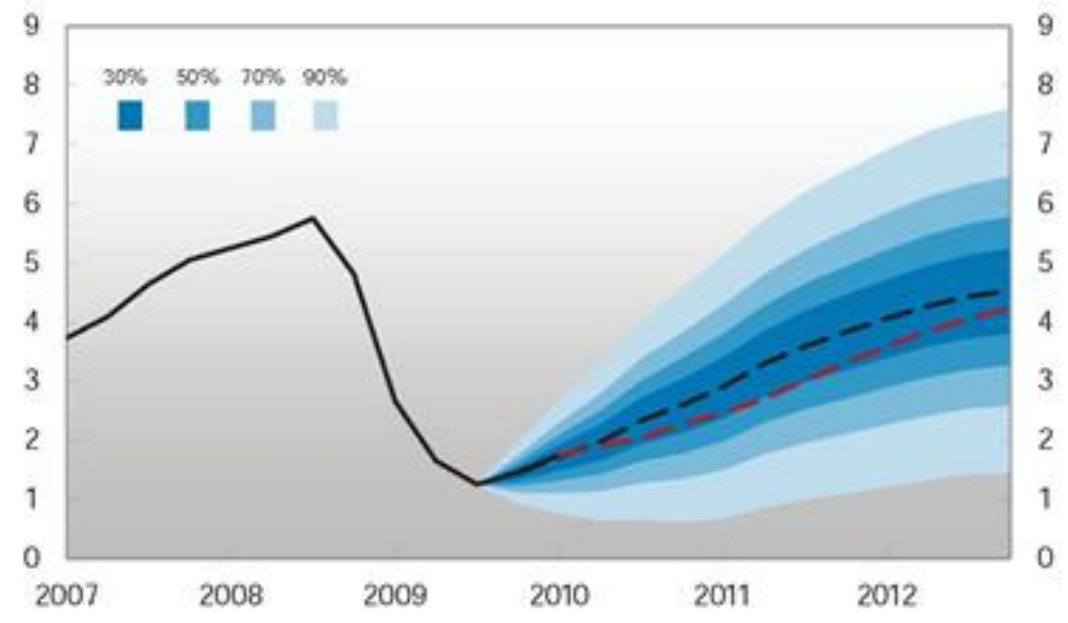

Source: Norges Bank

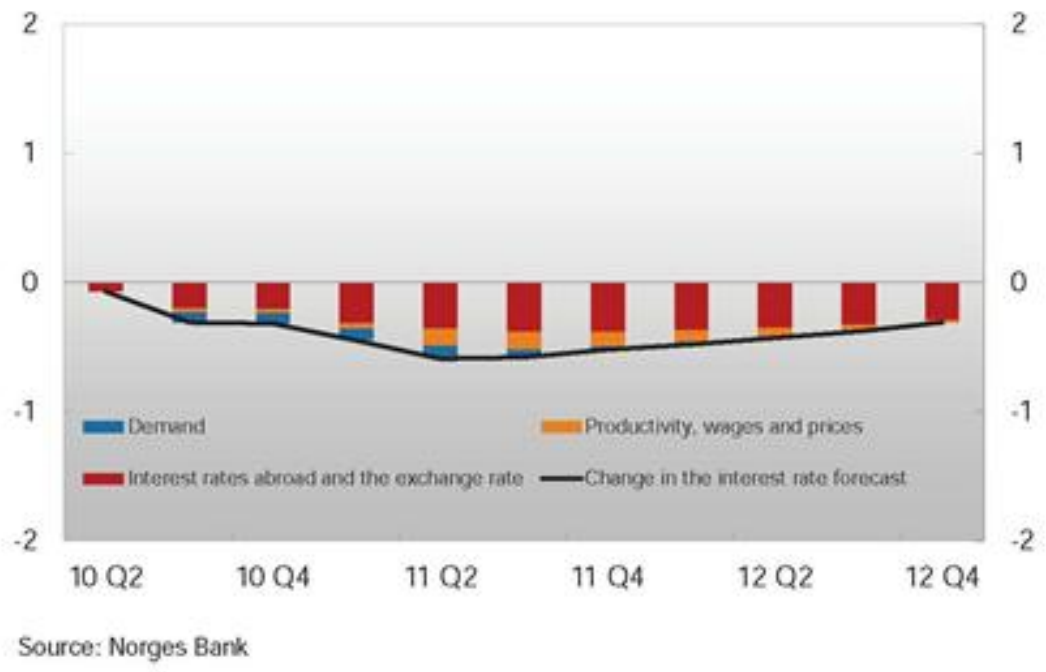

Figure 1 An illustration of the spillover of a cut in the foreign interest rate The top chart shows the decrease in the interest rate by the Norges Bank in 2010 and the bottom chart shows that the major contributor to the decision, according to the Norges Bank, was the decrease in interest rates abroad 

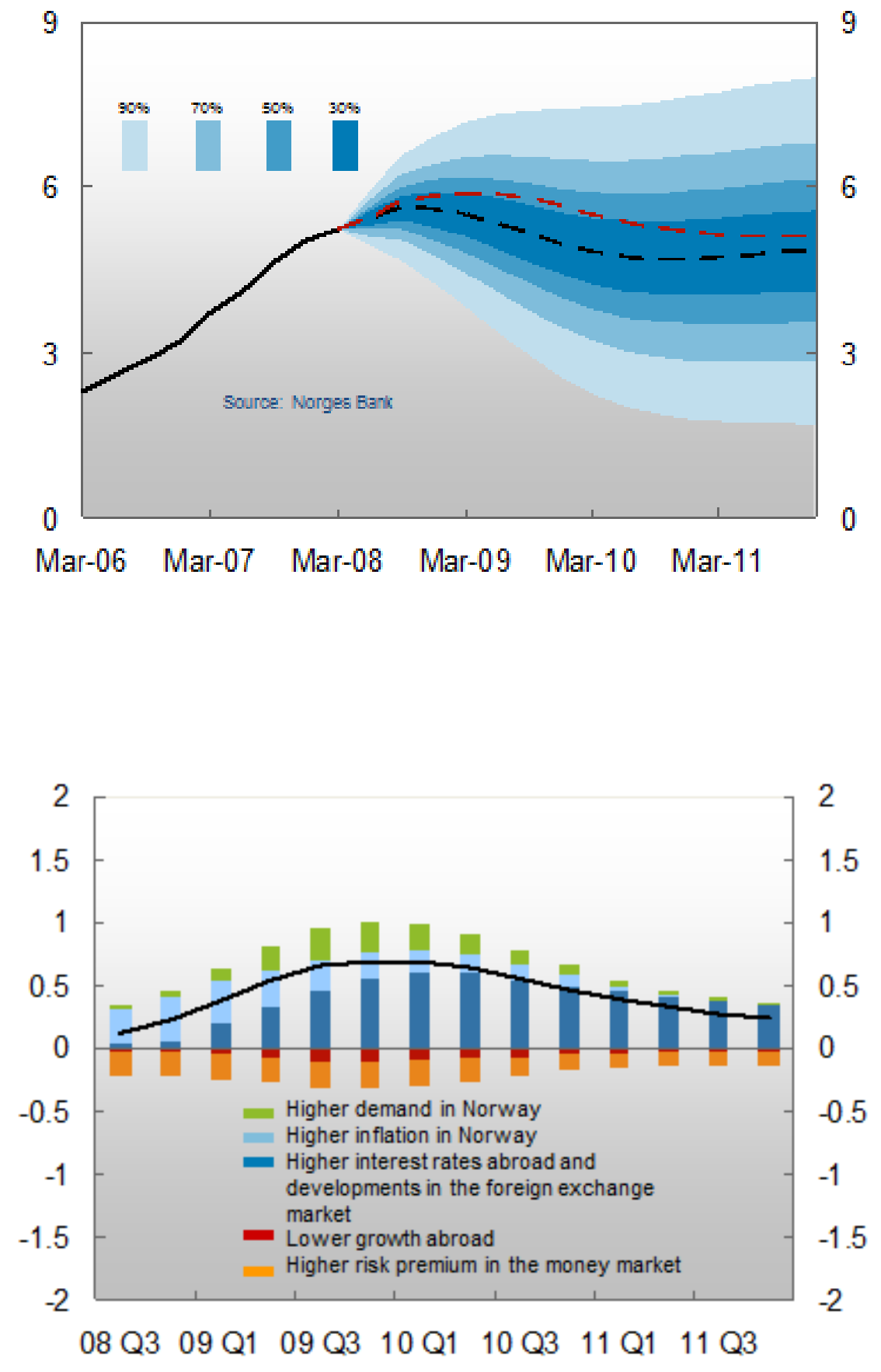

Figure 2 An illustration of the spillover of an increase in the foreign interest rate

The top chart shows the increase in the interest rate by the Norges Bank in early 2008 and the bottom chart shows that, according to the Norges Bank, the major contributor to the decision was the increase in interest rates abroad. 
The central banks reaction function or monetary policy rule is another way to show the spillover of central bank decision in other countries. Again, consider the Norges Bank's reports on its own policy rules. Figure 3 shows the interest rate setting in 2010 along with several policy rules that the Norges Bank uses and presents. The deviation of the actual policy rate (dashed red line) from the domestic monetary policy rule (either the blue or orange line) is clearly shown in the chart. That this deviation is almost entirely due to the very low interest rate abroad is shown by the policy rule with external interest rates included (green line) which comes much closer to describing the actions than the policy rules without external interest rates.

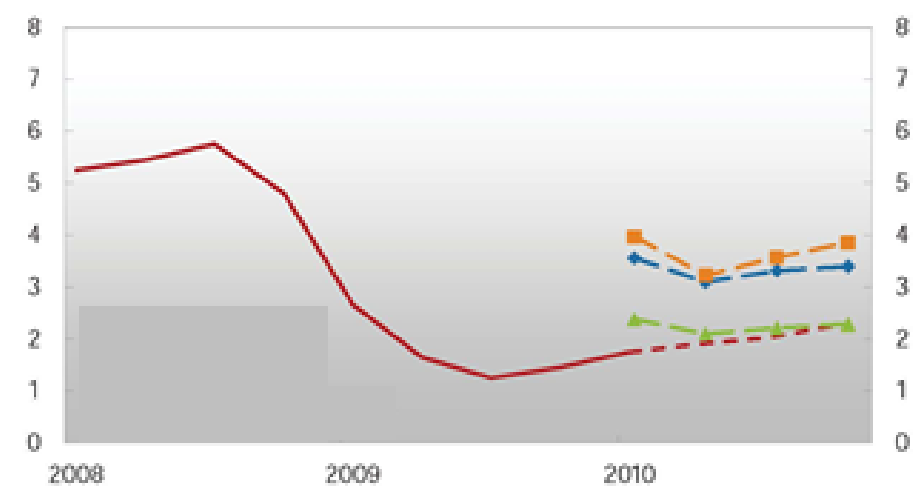

Taylor Rule - - - - -

Key Policy Rate - - - -

Rule with external interest rates - - - - -

Growth rule - - - -

Figure 3. Deviation from policy rule due to foreign central bank decisions.

While there are only a few central banks as transparent as the Norges Bank, there is econometric evidence from regressions using interest rate data from many other central banks. 
Using panel data from 12 central banks (Australia, Canada, South Korea, the United Kingdom, Norway, New Zealand, Denmark, Israel, Brazil, the Eurozone, China, and Indonesia), Gray (2012) estimated policy rate reaction functions in which the federal funds rate or other measures of foreign interest rates entered on the right hand side as deviations from their respective policy rates. He found that the average reaction coefficient on the foreign rate was large and significant. In Taylor (2007a) I estimated reaction functions and found that the coefficient on the federal funds rate in the ECB reaction function was large and significant during 2001-2006.

\section{Policy Spillover Amplification Mechanism}

While there is both theoretical and empirical evidence for spillovers of interest rate policy deviations, the effect of these spillovers can be amplified as central banks react to each other. To illustrate this amplification mechanism, consider a very simple two country model with policy spillovers. Let $i$ be the interest rate in one country—perhaps the United States—and $i^{*}$ be the interest rate in the other country, say the rest of the world. Let $z$ and $z^{*}$ symbolize domestic factors (a weighted average of inflation and real GDP, for example) in the central banks' policy rules. But also assume for the theoretical and empirical reasons stated above that the central banks deviate from these rules depending on interest rate settings at foreign central banks. Although the responses are likely to be quite complicated and may not even be part of the quantitative policy making apparatus, let us assume that the response is linear in the foreign interest rate. Then the policy rules (including the deviation from $z$ and $z^{*}$ ) can be written

$$
\begin{aligned}
& i=z+\alpha i^{*} \\
& i^{*}=z^{*}+\alpha^{*} i
\end{aligned}
$$


I assume that both $\alpha$ and $\alpha^{*}$ are positive and less than or equal to one. Thus the central banks follow each other to some degree in the model. Solving these equations for the interest rates in terms of $z$ and $z^{*}$ gives:

$$
\begin{aligned}
& i=\frac{1}{1-\alpha \alpha^{*}}\left(z+\alpha z^{*}\right) \\
& i^{*}=\frac{1}{1-\alpha \alpha^{*}}\left(z^{*}+\alpha^{*} z\right)
\end{aligned}
$$

Observe that the term multiplying the domestic factors in the above equations is greater than one. This is the spillover amplification mechanism which is caused by the banks responding to each other. Figure 4 illustrates this. It graphs the first two equations with $i$ on the vertical axis and $i^{*}$ on the horizontal axis in the case there $\alpha=.5$ and $\alpha^{*}=1$. If the Federal Reserve cuts its interest rate by 1 percentage point, for example, the rest of the world rate will also reduce rates by 1 percentage point, which causes the Fed to cut its interest rate by another .5 percentage point leading to another cut in the rest of the world, and so on. The new equilibrium is a 2 percentage point rate cut once other central banks and the Fed in turn react. In other words, the deviation from the policy rule is 1 percentage point in the United States, for this example, and 2 percentage points in the rest of the world. 


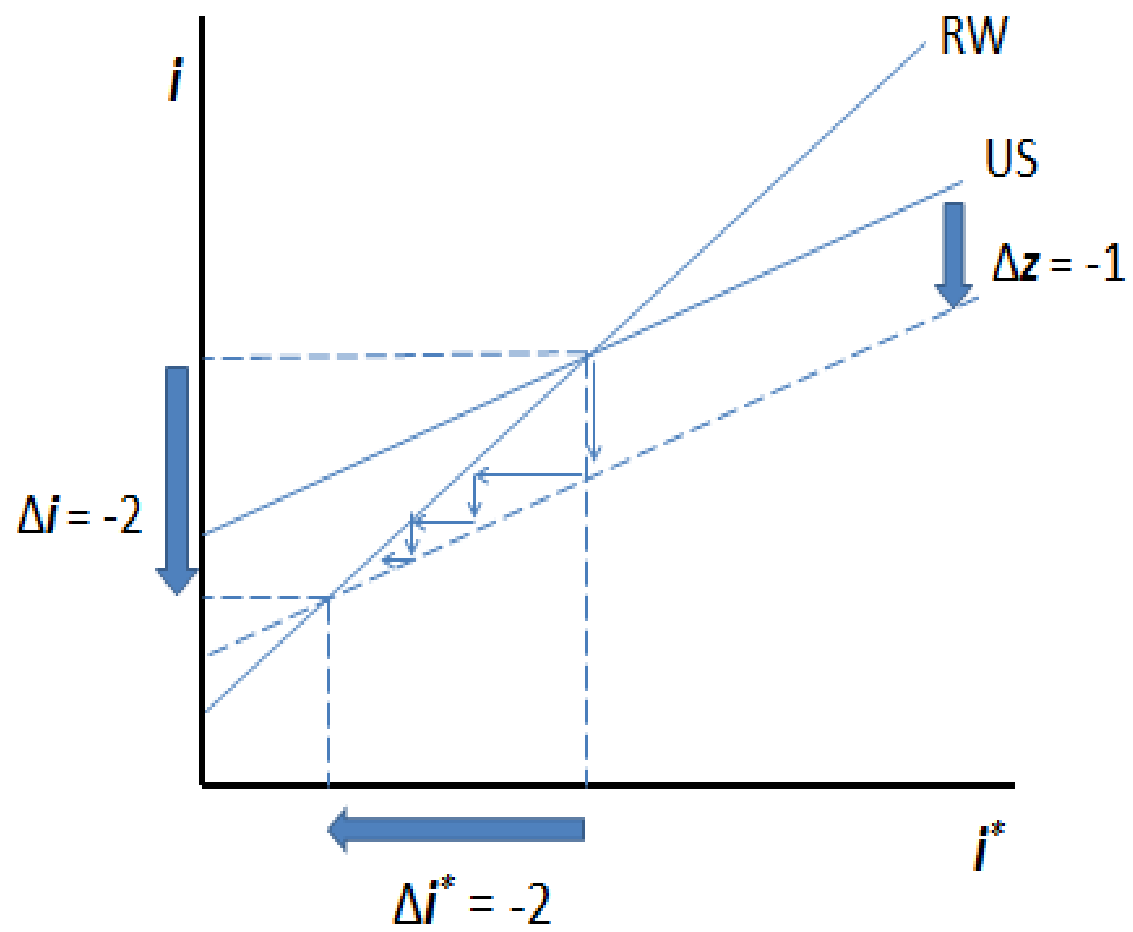

Figure 4 Policy Spillover Amplification Mechanism: Central banks react to other central banks' interest rate changes and a new equilibrium is reached after an initial change in domestic economic conditions.

\section{Capital Controls and Currency Intervention}

Perhaps because of these dangers, central banks have looked for other ways to avoid the interest rate impact of the unusually low interest rates of foreign central banks abroad. The most common alternatives are capital controls and currency market interventions. Capital controls are used to try to reduce the high levels of risky borrowing and to mitigate the currency appreciation. However, capital controls create market distortions and may lead to instability as borrowers and lenders try to get around them. Controls may also lead to other interventions as policy makers endeavor to find other controls to prevent the circumventions. For these reasons, capital 
controls are usually considered part of a good macroeconomic policy framework. They also run counter to the long term goal of an integrated global economy with higher economic growth.

Many central banks have used currency intervention to try to prevent appreciation of their currency in recent years. But even if the intervention is effective for a while it also creates economic problems.

For example currency interventions naturally lead to an accumulation of international reserves. These reserves must be invested somewhere. They might be invested in U.S. Treasury or mortgage backed securities in the United States, which tends to drive down these long term interest rates. In effect, the gross outflow of loans due to the low policy rates is matched, at least in part, by a gross inflow of funds from central banks into securities ${ }^{8}$

One example of the adverse effects of these flows has been pointed out by Borio and Disyatat (2011) and Beckworth and Crowe (2012). They argue that the low federal funds rate in the U.S in 2003-2005 may have led to such inflows of funds into mortgage backed securities and thus kept mortgage rates low, worsening the housing boom leading up to the financial crisis. This is in contrast to the view of Bernanke (2010) who argued that the low federal funds rate was not the reason for the boom in the housing market as I had found in Taylor (2007b). Rather Bernanke (2010) argued that the low long term rates were due to a savings glut — unrelated to monetary policy—by which the current account surpluses around the world caused the increased demand for U.S. mortgage securities.

\footnotetext{
${ }^{8}$ It is important to note that these gross flows occur without any change in the current account. Obstfeld (2012) emphasizes the importance of gross capital flow in comparison with the current account in his 2012 Ely Lecture, but does not develop the monetary policy connection. That too much focus on the current account can take attention away from these gross flows was a concern to me when I served as U.S. Treasury Under Secretary from 2001-2005. See (Taylor (2004).
} 


\section{Concluding Remarks}

Most discussions of international policy coordination focus on current account imbalances — both surpluses and deficits. The term "rebalancing" refers to the coordinated policy actions of different countries to reduce these imbalances. In this paper I considered another equally important type of international imbalance that has received far less attention. It pertains to monetary policy, and occurs when discretionary deviations from rules-based monetary policy at one or more large central banks create incentives or pressures on other central banks to also deviate from such policies. In the past decade economists have documented such policy deviations at many central banks providing evidence of such an international monetary imbalance problem. In particular, starting about ten years ago policy interest rates in a number of countries were held below rates implied by monetary policy rules that worked during the Great Moderation, which in my view represented a more balanced international situation. These policy deviations can have a variety of adverse effects on economic performance, as Bordo and Lane (2012) have recently shown. The deviations from a more rules-based interest rate policy have continued at many central banks since the financial crisis ended, especially if one includes unconventional interventions such as quantitative easing.

Several reasons for the spillover of these deviations were pointed out in this paper, including the desire to prevent excessive exchange rate fluctuations and risk-taking, though political pressures or common factors may also be at work. Whatever the reason, there is plenty of empirical support that central banks respond this way.

Moreover, with central banks around the world responding this way there is a spillover amplification mechanism which can create even larger deviations from policy rules. Efforts to avoid this interest rate response through currency intervention or capital controls create 
additional harmful side effects. Indeed, one of those harmful side effects may have been the international capital flow into long term bond markets in the United States which accentuated the boom leading to the financial crisis in 2008 .

The adverse effects on economic performance illustrate the advantages of a more balanced rules-based policy similar to what existed during the Great Moderation period. Unlike in the situation during the Great Moderation, which appears to be well described by models in which international monetary policy coordination has a relatively small benefit, international coordination might be quite useful in this rebalancing. 


\section{References}

Ahrend, Rudiger (2010), "Monetary Ease: A Factor Behind Financial Crises? Some Evidence from OECD Countries,” Economics: The Open Access, Open Assessment E-Journal, 4

Beckworth, David and Christopher Crowe (2012) "The Great Liquidity Boom and the Monetary Superpower Hypotheses," in Boom and Bust in Banking: Causes and Cures of the Great Recession, David Beckworth, (Ed.), Oakland California: The Independent Institute. 17-54

Bekaert, Geert, Marie Hoerova, and Marco Lo Duca (2010), "Risk, Uncertainty and Monetary Policy,” NBER Working Paper Number 16397, September

Bernanke, Ben. (2010) "Monetary Policy and the Housing Bubble", speech delivered at the American Economic Association meeting in Atlanta

Bordo, Michael and John Landon Lane (2012) "Does Expansionary Monetary Policy Cause Asset Price Booms: Some Historical and Empirical Evidence,” Rutgers University Borio, Claudio and Piti Disyatat (2011), “Global Imbalances and the Financial Crisis: Link or No Link?” Bank for International Settlements, Working Paper, 346, May.

Bruno, Valentina and Hyun Song Shin (2012), "Capital Flows and the Risk-Taking Channel of Monetary Policy," paper presented at the 11th BIS Annual Conference, June.

Caruana, Jamie (2012a), “Policymaking in an Interconnected World,” presented at Federal Reserve Bank of Kansas City Policy Symposium on The Changing Policy Landscape, Jackson Hole, Wyoming, August 31

Caruana, Jamie (2012b), "International Monetary Policy Interactions: Challenges and Prospects," Speech in Punta del Este, Uruguay, 16 November

Gray, Colin (2012), “Responding to a Monetary Superpower: Investigating the Behavioral Spillovers of U.S. Monetary Policy,” Department of Economics, Stanford University. 
Hofmann, Boris and Bilyana Bogdanova (2012), “Taylor Rules and Monetary Policy: A Global Great Deviation?" BIS Quarterly Review, September 2012

Kahn, George A. (2010), “Taylor Rule Deviations and Financial Imbalances.” Federal Reserve Bank of Kansas City Economic Review, Second Quarter, 63-99.

Obstfeld, Maurice (2012) “Does the Current Account Still Matter?" American Economic Review, Papers and Proceedings, May

Oudiz, Gilles and Jeffrey Sachs, (1984), "Macroeconomic Policy Coordination Among the Industrial Economies," Brookings Papers on Economic Activity, Vol, 1, pp. 1-64

OECD (2010) Economic Survey: Norway, p. 32

Røisland, Øistein (2010), “Monetary Policy in Norway,” Slide presentation, Norges Bank Taylor, John B. (1985), "International Coordination in the Design of Macroeconomic Policy Rules,” European Economic Review, 28, 1985, pp. 53-81

Taylor, John B. (2004) “The U.S. Current Account: Recent Trends and Policies,” Speech at American Enterprise Institute, Washington, D.C. November 4

Taylor, John B. (2007a), “Globalization and Monetary Policy: Missions Impossible,” NBER Conference, Girona Spain, June, in M. Gertler and J. Gali (Eds.), The International Dimensions of Monetary Policy. Chicago: University of Chicago Press, 2010, 609-624

Taylor, John B. (2007b), “Housing and Monetary Policy,” (2007b) in Housing, Housing Finance, and Monetary Policy, Federal Reserve Bank of Kansas City, Sept., pp. 463-476.

Taylor, John B. (2010), “Simple Rules for Open Economies,” Norges Bank Conference On the Use of Simple Rules as Guidelines for Policy Decisions, Oslo, June, (Slides)

Weiland, Volker, Tobias Cwik, Gernot Mueller, Sebastian Schmidt and Maik Wolters (2009),"A New Comparative Approach to Macroeconomic Modeling and Policy Analysis," Center for Financial Studies, Frankfurt. 